\title{
Cash-in-Advance Constraint with Status in a Neoclassical Growth Model
}

\author{
Ken-ichi Kaminoyama ${ }^{*}$, Taketo Kawagishi ${ }^{2}$ \\ ${ }^{1}$ Department of Economics, Doshisha University, Kyoto, Japan \\ ${ }^{2}$ Faculty of Economics, Tezukayama University, Nara, Japan \\ Email: *obenberg1029@hotmail.co.jp, tkawagishi@tezukayama-u.ac.jp
}

Received August 22, 2013; revised September 25, 2013; accepted October 7, 2013

Copyright (c) 2013 Ken-ichi Kaminoyama, Taketo Kawagishi. This is an open access article distributed under the Creative Commons Attribution License, which permits unrestricted use, distribution, and reproduction in any medium, provided the original work is properly cited.

\begin{abstract}
In this paper, we assume that a cash-in-advance (CIA) constraint itself depends on relative income, which implies the status. This constraint means that agents with higher income are more creditworthy and can make purchases with fewer money holdings. Under this assumption, we construct a one-sector neoclassical growth model and show that there exists a unique steady state that has saddle-path stability without specifying each function. Furthermore, we examine the effects of money growth on capital accumulation. If the status elasticity of CIA constraint is large, the Tobin effect can arise. In contrast, if it is small, the anti-Tobin effect can arise.
\end{abstract}

Keywords: Cash-in-Advance Constraint; Status; Money Growth; Neoclassical Growth Model; Tobin/Anti-Tobin Effect

\section{Introduction}

There is a growing macroeconomic literature that examines the effects of inflation (money growth) on capital accumulation. Tobin [1] regards money as a substitute for capital and concludes that money growth accelerates capital accumulation, known as the Tobin effect. Thereafter, many studies have discussed the effects of money growth in the context of cash-in-advance (CIA henceforth) constraints. For example, Clower [2] and Lucas [3] show that if the CIA constraint applies only to consumption, then money growth has no effect on capital accumulation in the long run, known as the superneutrality of money. On the other hand, Stockman [4] considers a standard neoclassical growth model with the CIA constraint applying to both consumption and investment, and shows that money growth decreases capital accumulation. This is because after the period of higher inflation the net rate of return on capital falls. In this case, the level of capital and the money growth rate are negatively correlated. This is referred to as the anti-Tobin effect.

Recent studies on neoclassical growth models with CIA constraints capture the role of status in terms of a social device providing priority in the nonmarket goods

*Corresponding author. sector, seen in Cole et al. [5]. ${ }^{1}$ In this context, Chang et al. [8], Gong and Zou [9], and Chang and Tsai [10] introduce status, defined as capital holdings, into preferences. $^{2}$ Under the Clower-Lucas-type CIA constraint, Chang et al. [8] confirm that money growth and the steady-state level of capital are positively correlated. It is because higher inflation increases the cost of money holdings, that the agent shifts his/her assets from money to capital, which provides utility. On the other hand, Gong and Zou [9] employ the Stockman-type CIA constraint and show that whether money growth promotes capital accumulation or not depends on the measure of the agent's desire for status. ${ }^{3}$ In a similar vein, Chang and Tsai [10] find that when the status seeking effect dominates the inflation tax effect, money growth and the steady-state capital stock are positively correlated under the general-type CIA constraint, which means that whole consumption and a positive fraction of investment are

\footnotetext{
${ }^{1}$ Zou [6] interprets utility from capital in terms of the spirit of capitalism, based on Weber [7], and shows that endogenous growth can arise even if the interest rate is smaller than the time preference rate.

${ }^{2}$ This type of preferences had already been constructed mathematically by Kurz [11].

${ }^{3}$ Gong and Zou [9] analyze the effects of money growth in the case of the Clower-Lucas-type CIA constraint and that of the Stockman-type CIA constraint. Under the Clower-Lucas-type CIA constraint, Gong and Zou [9] obtain the same results as in Chang et al. [8].
} 
purchased using real money balances.

In this paper, on the other hand, we capture the status in terms of social credibility when making purchases. Specifically, we embody this concept by assuming that individuals with higher income (higher status) are more creditworthy and can make purchases with fewer money holdings. Avery et al. [12] show that high income individuals use cash and cash plus checks for a smaller fraction of their total transactions than low income individuals; and Wolff [13], Kessler and Wolff [14], and Kennickell and Starr-McCluer [15] find that the fraction of household wealth held in liquid assets decreases with income and wealth. Hence, in the present study, we assume that the CIA constraint itself depends on relative income, which implies status, and that this CIA constraint applies to consumption and investment. Under such a CIA constraint, we consider a neoclassical growth model and clarify how status has an impact on the relationship between the rate of money growth and the steady-state level of capital, as well as a uniqueness of the steady state and its stability.

\section{Model}

\subsection{CIA-Status Constraint}

The representative agent faces the following CIA constraint:

$$
m \geq l_{c} c+l_{i} i, \quad 0<l_{c}, l_{i} \leq 1,
$$

where $c$ is consumption, $i$ is investment, and $m$ is real money balances defined as nominal money balances divided by the price level. ${ }^{4}$ In addition, $l_{c}$ and $l_{i}$ are the ratios of consumption and investment goods which require cash, respectively.

From the observations mentioned in the Introduction (Avery et al. (1987) etc.), we assume that $l_{c}$ and $l_{i}$ depend on the agent's credit when making purchases:

$$
l_{c}=\Omega\left(\frac{y}{\bar{y}}\right), l_{i}=x \Omega\left(\frac{y}{\bar{y}}\right), 0<x \leq 1,
$$

where $y$ and $\bar{y}$ are private income and average income in the economy respectively, and $y / \bar{y}$ stands for the agent's own relative income. ${ }^{5}$ Note that we regard relative income as status. Additionally, $x$ represents the relative strength of the liquidity constraint applying to investment expenditure. Along the lines of the standard CIA literature, we assume that the liquidity constraint on consumption is stricter than that on investment. Moreover, we posit that $\Omega(\cdot)$ is decreasing and convex with respect to $y / \bar{y}$ :

\footnotetext{
${ }^{4}$ To simplify the notation, we drop the time index from each variable. ${ }^{5}$ Note that, from (1) and (2), $\Omega(\cdot) \in(0,1]$.
}

$$
\Omega^{\prime}\left(\frac{y}{\bar{y}}\right) \leq 0, \Omega^{\prime \prime}\left(\frac{y}{\bar{y}}\right) \geq 0 .
$$

From (1) and (2), we have

$$
m \geq \Omega\left(\frac{y}{\bar{y}}\right)(c+x i) .
$$

In the following analysis, we impose (4), referred to as the CIA-status constraint.

\subsection{Optimal Conditions and Dynamic System}

The economy is inhabited by a continuum of identical, infinite-lived agents endowed with a unit of labor. The size of the population is constant and is normalized to unity. Each agent consumes a continuum of non-perishable consumption goods produced with a simple neoclassical production technology. We assume that each consumption commodity is perfectly complementary. The representative agent maximizes the following lifetime utility:

$$
\int_{0}^{\infty} u(c) \mathrm{e}^{-\theta t} \mathrm{~d} t
$$

where $u(\cdot)$ is an instantaneous utility function which satisfies $u^{\prime}(\cdot)>0, u^{\prime \prime}(\cdot)<0$ and the Inada conditions $\left(\lim _{c \rightarrow \infty} u^{\prime}(c)=\infty, \lim _{c \rightarrow \infty} u^{\prime}(c)=0\right)$. In addition, $\theta(>0)$ is the constant rate of time preference.

The budget constraint of the representative agent is

$$
\dot{m}=f(k)-c-i-\pi m+\tau,
$$

where $k$ is capital stock and $\pi$ is the rate of inflation. Output is produced using a neoclassical production function, $f(\cdot)$, satisfying $f^{\prime}(\cdot)>0, f^{\prime \prime}(\cdot)<0$ and the Inada conditions $\left(\lim _{k \rightarrow 0} f^{\prime}(k)=\infty, \lim _{k \rightarrow \infty} f^{\prime}(k)=0\right)$.

The law of motion of capital stock is

$$
\dot{k}=i \text {, given } k_{0}>0 \text {. }
$$

For simplicity, the depreciation rate of capital is assumed to be zero. In (6), $\tau$ is the seigniorage that the agent receives from the monetary authority as a lumpsum transfer:

$$
\tau=\phi m,
$$

where $\phi$ is the constant, time-invariant money growth rate. By using $\phi$, the nominal money supply, $M$, is expressed as

$$
M_{t}=M_{0} \mathrm{e}^{\phi t} \text {, given } M_{0}>0 .
$$

Assuming a representative agent and a neoclassical technology, from (4), we find that the CIA-status constraint becomes 


$$
m \geq \Omega\left(\frac{f(k)}{f(\bar{k})}\right)(c+x i),
$$

where $\bar{k}$ is average capital stock in the economy.

The representative agent maximizes (5) subject to (6), (7) and (10). In this problem, the representative agent is assumed to take the sequences, $\left\{\bar{k}_{t}\right\}_{t=0}^{\infty}$, as given. To derive the necessary conditions for an optimum, we set up the following current-value Hamiltonian function:

$$
\begin{aligned}
H & =u(c)+\lambda[f(k)-c-i-\pi m+\tau] \\
& +\mu[i]+\eta\left[m-\Omega\left(\frac{f(k)}{f(\bar{k})}\right)(c+x i)\right],
\end{aligned}
$$

where $\lambda$ and $\mu$ are the shadow prices of real money balances and the capital stock, respectively, and $\eta$ is the Lagrange multiplier associated with the CIA-status constraint (10). The first-order conditions for optimization are given as follows:

$$
\begin{aligned}
& u^{\prime}(c)=\lambda+\eta \Omega\left(\frac{f(k)}{f(\bar{k})}\right), \\
& \mu=\lambda+x \eta \Omega\left(\frac{f(k)}{f(\bar{k})}\right), \\
& \dot{\mu}=\theta \mu-\lambda f^{\prime}(k)+\eta \Omega^{\prime}\left(\frac{f(k)}{f(\bar{k})}\right) \frac{f^{\prime}(k)}{f(\bar{k})}(c+x i), \\
& \dot{\lambda}=\lambda(\pi+\theta)-\eta,
\end{aligned}
$$

and the transversality conditions for $k$ and $m$ are

$$
\begin{aligned}
& \operatorname{lime}_{t \rightarrow \infty} \mathrm{e}^{-\theta t} \mu k=0, \\
& \operatorname{lime}_{t \rightarrow \infty} \mathrm{e}^{-\theta t} \lambda m=0 .
\end{aligned}
$$

Equation (11) implies that the marginal utility of consumption equals the marginal cost of consumption, which is the marginal utility of having an additional unit of real money balances. Equations (12) and (13) together indicate the evolution of capital over time, where the last term on the left-hand side in (13) represents the marginal benefit from the higher income position (i.e. higher status). This benefit implies that the agent gets relatively higher credibility and can make purchases with fewer money holdings. Equation (14) implies that the marginal value of real money balances equals the marginal cost.

Since the agents are assumed to be symmetric and the size of the population is unity, in equilibrium, the level of the agent's capital stock is equal to the average level of capital stock in the economy:

$$
k=\bar{k} \text {. }
$$

Additionally, in equilibrium, the goods market clears, and money demand is equal to money supply:

$$
\begin{gathered}
\dot{k}=f(k)-c, \\
\dot{m}=(\phi-\pi) m .
\end{gathered}
$$

We assume that the CIA constraint is always binding in equilibrium, as is common in the CIA literature. Thus, from (10) and (17), we get

$$
m=\Omega(1)(c+x i) .
$$

From (7) and (11) - (20), we obtain the following dynamic system after some manipulation:

$$
\begin{aligned}
\dot{c}= & -D^{-1}\left[( 1 - x ) \left\{\lambda\left(\phi-\frac{x f^{\prime}(k) \dot{k}}{x f(k)+(1-x) c}\right)\right.\right. \\
& \left.-\frac{\left(u^{\prime}(c)-\lambda\right)}{\Omega(1)}\right\}+\lambda f^{\prime}(k)-\theta x u^{\prime}(c) \\
+ & \left.\xi\left(u^{\prime}(c)-\lambda\right)\{x f(k)+(1-x) c\} \frac{f^{\prime}(k)}{f(k)}\right], \\
\dot{\lambda}= & -\frac{\left(u^{\prime}(c)-\lambda\right)}{\Omega(1)} \\
& +\lambda\left\{\theta+\phi-\frac{x f^{\prime}(k) \dot{k}+(1-x) \dot{c}}{x f(k)+(1-x) c}\right\}, \\
\dot{k}= & f(k)-c,
\end{aligned}
$$

where

$$
\begin{aligned}
& D \equiv\left\{x u^{\prime \prime}(c)-\frac{(1-x)^{2} \lambda}{x f(k)+(1-x) c}\right\}<0, \\
& \xi \equiv-\frac{\Omega^{\prime}(1)}{\Omega(1)}>0 .
\end{aligned}
$$

Note that $\xi$ expresses the elasticity of the CIA constraint with respect to status.

\subsection{Steady State and Stability}

In this subsection, we consider a steady state and its stability. In a steady state, the economy is characterized by $\dot{c}=\dot{\lambda}=\dot{k}(=\dot{m})=0$. Substituting this condition into (21)-(23) and calculating them, we obtain

$$
\begin{aligned}
& f^{\prime}\left(k^{*}\right)\{1+\xi(\theta+\phi) \Omega(1)\} \\
& =\theta\{1+x(\theta+\phi) \Omega(1)\} .
\end{aligned}
$$

Since the production function, $f(\cdot)$, satisfies concavity and the Inada conditions, we have a unique solution, 
$k^{*}$, which represents the steady-state level of capital. Equation (24) implies that when the CIA constraint itself depends on status $(\xi>0)$, the steady-state level of capital is not determined only by the constant rate of time preference (i.e. the modified golden rule $\left(f^{\prime}(k)=\theta\right)$ does not hold), even if the CIA constraint applies only to consumption $(x=0)$. In this case, the level of capital hinges on money growth, that is, the superneutrality of money is not valid. In the next section, we conduct the analysis concerning the effects of money growth on capital stock and consumption.

Next, we consider the stability of the steady state. Linearizing the dynamic system (21)-(23) around the steady state, we obtain the following relationships among the three characteristic roots, $g_{1}, g_{2}$ and $g_{3}$ (note that $c^{*}$ represents the steady-state level of consumption): ${ }^{6}$

$$
\begin{aligned}
& g_{1}+g_{2}+g_{3}=-\frac{(1-x) \xi f^{\prime}\left(k^{*}\right) u^{\prime}\left(c^{*}\right)}{D^{*} f\left(k^{*}\right)}+\theta \\
& +\frac{\left(f^{\prime}\left(k^{*}\right)+\phi\right) u^{\prime \prime}\left(c^{*}\right)}{D^{*}} \\
& \times\left\{\frac{1}{(\theta+\phi) \Omega(1)}+x\right\}>0, \\
& g_{1} g_{2} g_{3}=-\frac{\{1+\xi(\theta+\phi) \Omega(1)\} f^{\prime \prime}\left(k^{*}\right) u^{\prime}\left(c^{*}\right)}{D^{*} \Omega(1)}<0,
\end{aligned}
$$

where

$$
D^{*} \equiv\left[x u^{\prime \prime}\left(c^{*}\right)-\frac{(1-x)^{2} u^{\prime}\left(c^{*}\right)}{\{1+(\theta+\phi) \Omega(1)\} f\left(k^{*}\right)}\right]<0 .
$$

Equations (25) and (26) together indicate that the dynamic system has one negative and two positive eigenvalues. Since consumption, $c$, and the shadow price of real money balances, $\lambda$, are jumpable variables and capital stock, $k$, is a state variable, the steady state exhibits the saddle-point stability.

Proposition 1. In a neoclassical growth model with the CIA-status constraint (4), there exists a unique steady state that is saddle-path stable.

\section{Effects of Money Growth on Capital Stock}

In this section, we clarify how money growth affects the steady-state level of capital stock and that of consumption in our framework.

From (24), we have

$$
\frac{\mathrm{d} k^{*}}{\mathrm{~d} \phi} \gtreqless 0 \Leftrightarrow \xi \gtreqless x .
$$

${ }^{6}$ Details for the linearization of the dynamic system are available from the authors on request.
Expressions (27) indicate that when the status elasticity of the CIA constraint, $\xi$, is greater (resp. smaller) than the relative strength of the liquidity constraint applying to investment expenditure, $x$, an increase in the rate of money growth, $\phi$, induces an increase (resp. a decrease) in capital stock. The positive (resp. negative) relationship between the rate of money growth and capital stock can be considered as the presence of the Tobin (resp. the anti-Tobin) effect.

These results can be interpreted through the relationship between the benefit of holding additional capital stock and the cost of purchasing investment goods. Here, the benefit is generated from the status enhancement effect, which arises when the agent makes the CIA constraint less restricted by investing more. This benefit can be captured through the parameter $\xi$. On the other hand, the cost is caused by the inflation tax effect, which occurs when the agent purchases investment goods after the policy of raising money growth induces higher inflation. This cost can be measured by the parameter $x$.

The intuition is as follows. Suppose that the economy is in the steady state initially, and that the rate of money growth rises. When $\xi$ is greater than $x$, the status enhancement effect dominates the inflation tax effect; that is, the benefit of holding additional capital stock generated from the status enhancement effect is greater than the cost of purchasing investment goods caused by the inflation tax effect. In this case, if the agent holds additional capital stock, his/her income increases, so that he/she obtains higher status and holds less money balances through the CIA-status constraint. This implies that the agent can avoid paying the higher inflation tax caused by the money growth on the future consumption, which leads to an increase in the future real consumption. Thus, since the net rate of return on capital in utility terms increases, the agent shifts his/her demand from current consumption to capital stock. ${ }^{7,8}$ As a result, a rise in the money growth rate accelerates capital accumulation, which leads to an increase in output and that in consumption in the long run.

In contrast, when $\xi$ is smaller than $x$, the inflation tax effect dominates the status enhancement effect. Thus, an increase in money growth depresses the steady-state level of capital, which leads to a decrease in output and that in consumption in the long run.

Proposition 2. In a neoclassical growth model with the CIA-status constraint (4), if the status elasticity of the

\footnotetext{
${ }^{7}$ Actually, as the third effect, there is the inflation tax effect on purchasing current and future consumption goods. When $\xi=x=0$, we can extract only this third effect. However, Stockman (1981) focuses on this case and shows that the net rate of return on capital in utility (consumption) terms is unaffected by higher inflation. Thus, we ignore this third effect.

${ }^{8}$ Note that the agent obtains the higher net rate of return on capital by investing more and enhancing his/her status.
} 
CIA constraint is greater (smaller) than the relative strength of the liquidity constraint applying to investment expenditure (i.e. $\xi>(<) x)$, then a rise in the money growth rate increases (decreases) the steady-state level of capital and that of consumption.

\section{Conclusions}

This paper has investigated a neoclassical growth model with a CIA constraint and itself depends on relative income, which implies status. Under this assumption, we have examined how status, which affects the CIA constraint, has an impact on the relationship between money growth and capital stock, as well as a uniqueness of the steady state and its stability.

Under the CIA-status constraint, we have shown that 1) there exists a unique steady state that has saddle-path stability without specifying each function, and 2) the Tobin or the anti-Tobin effect arises depending on the magnitude relationship between the status elasticity of the CIA constraint and the relative strength of the liquidity constraint applying to investment expenditure.

\section{Acknowledgements}

We would like to express our profound gratitude to Kazuo Mino and the anonymous referee, who gave us helpful and valuable comments while we were writing this paper.

\section{REFERENCES}

[1] J. Tobin, “Money and Economic Growth,” Econometrica, Vol. 33, No. 4, 1965, pp. 671-684. http://dx.doi.org/10.2307/1910352

[2] R. W. Clower, "A Reconsideration of the Microfoundations of Monetary Theory," Western Economic Journal, Vol. 6, No. 1, 1967, pp. 1-8.

[3] R. E. Lucas, "Equilibrium in a Pure Currency Economy," Economic Inquiry, Vol. 18, No. 2, 1980, pp. 203-220. http://dx.doi.org/10.1111/j.1465-7295.1980.tb00570.x

[4] A. C. Stockman, "Anticipated Inflation and the Capital Stock in a Cash-in-Advance Economy," Journal of Monetary Economics, Vol. 8, No. 3, 1981, pp. 387-393. http://dx.doi.org/10.1016/0304-3932(81)90018-0
[5] H. L. Cole, G. J. Mailath and A. Postlewaite, "Social Norms, Savings Behavior, and Growth,” The Journal of Political Economy, Vol. 100, 1992, pp. 1092-1125. http://dx.doi.org/10.1086/261855

[6] H. F. Zou, “'The Spirit of Capitalism' and Long-Run Growth," European Journal of Political Economy, Vol. 10, No. 2, 1994, pp. 279-293. http://dx.doi.org/10.1016/0176-2680(94)90020-5

[7] M. Weber, "The Protestant Ethic and the Spirit of Capitalism,” Charles Scribner's Sons, New York, 1958.

[8] W. Y. Chang, Y. N. Hsieh and C. C. Lai, "Social Status, Inflation and Endogenous Growth in a Cash-in-Advance Economy,” European Journal of Political Economy, Vol. 16, No. 3, 2000, pp. 535-545. http://dx.doi.org/10.1016/S0176-2680(00)00011-2

[9] L. Gong and H. F. Zou, "Money, Social Status, and Capital Accumulation in a Cash-in-Advance Model," Journal of Money, Credit and Banking, Vol. 33, No. 2, 2001, pp. 284-293. http://dx.doi.org/10.2307/2673886

[10] W. Y. Chang and H. F. Tsai, "Money, Social Status, and Capital Accumulation in a Cash-in-Advance Model: A Comment," Journal of Money, Credit and Banking, Vol. 35, 2003, pp. 657-661. http://dx.doi.org/10.1353/mcb.2003.0027

[11] M. Kurz, "Optimal Economic Growth and Wealth Effects,” International Economic Review, Vol. 9, No. 3, 1968, pp. 348-357. http://dx.doi.org/10.2307/2556231

[12] R. Avery, G. Elliehausen and A. Kennickell, "Changes in the Use of Transaction Accounts and Cash from 1984 to 1986,” Federal Reserve Bulletin, Vol. 73, No. 3, 1987, pp. 179-195.

[13] E. Wolff, “The Size Distribution of Household Disposable Wealth in the United States," Review of Income and Wealth, Vol. 29, 1983, pp. 125-146. http://dx.doi.org/10.1111/j.1475-4991.1983.tb00636.x

[14] D. Kessler and E. Wolff, “A Comparative Analysis of Household Wealth Patterns in France and the United States," Review of Income and Wealth, Vol. 37, No. 3, 1991, pp. 249-266. http://dx.doi.org/10.1111/j.1475-4991.1991.tb00370.x

[15] A. Kennickell and M. Starr-McCluer, "Household Saving and Portfolio Change: Evidence from the 1983-1989 SCF Panel," Review of Income and Wealth, Vol. 43, No. 4, 1997, pp. 381-399. http://dx.doi.org/10.1111/j.1475-4991.1997.tb00232.x 